\title{
Preservation of an ancient grassland biomarker signature in a forest soil from the French Massif Central
}

Marlène Lavrieux ${ }^{\mathrm{a}, \mathrm{b}^{*}}$, Jean-Gabriel Bréheret ${ }^{\mathrm{a}}$, Jean-Robert Disnar ${ }^{\mathrm{b}}$, Jérémy Jacob ${ }^{\mathrm{b}}$, Claude Le Milbeau $^{\text {b }}$, Renata Zocatelli ${ }^{\mathrm{b}}$

${ }^{a}$ GéHCo - Géohydrosystèmes continentaux, EA 6293, Faculté des Sciences et Techniques, Université François Rabelais de Tours, Parc Grandmont, F-37200 Tours, France

${ }^{\mathrm{b}}$ Institut des Sciences de la Terre d'Orléans, Université d'Orléans, ISTO, UMR 7327, 45071, Orléans, France ; CNRS/INSU, ISTO, UMR 7327, 45071 Orléans, France ; BRGM, ISTO, UMR 7327, BP 36009, 45060 Orléans, France

\section{ABSTRACT}

In response to the lack of studies focussing on the residence time of molecular biomarkers in soils, the lipid content of three soil profiles from the French Massif Central with different land use history were examined. The free neutral lipid content of two reference soil profiles developed under grassland and forest vegetation, and of a former grassland soil converted to forest about 60 years ago, was analysed using gas chromatography - mass spectrometry (GC-MS). Wax esters as well as the ratio of major homologues of $n$-alkanes and $n$-alkan-2-ones could be used to characterize the overlying vegetation in the reference forest and grassland soil profiles, but failed to distinguish the respective grassland and forest contributions to the profile of the soil that had changed use. For $n$-alkanes and $n$-alkan-2-ones, the failure might be attributed either to mixing of the molecular patterns inherited for the former and current plant cover, whereas for compounds such as wax esters simple degradation is likely to be involved. Conversely, iso- and anteiso- $\mathrm{C}_{15: 0}$ fatty acid methyl esters (FAMEs; of bacterial origin), steroids (tracing cattle faecal contamination), tricyclic diterpenoids and their oxygenated derivatives, as well as methoxyserratenes (inherited from Pinaceae) and triterpenyl acetates (specific to the Asteraceae), proved to be effective in distinguishing current land use for the reference soil profilesand for the converted soil. The persistence of these compounds in the changed use soil allowed us to estimate their residence time in soil.

Keywords: Soils; Biomarkers; Land use changes; Grassland / Pasture; Conifer forest; French Massif Central.

\footnotetext{
* Corresponding author. Tel.: +33 (0)2 384172 26; fax: +33 (0)2 38636488.

E-mail address: marlene.lavrieux@etu.univ-tours.fr (M. Lavrieux).
} 


\section{Introduction}

Knowledge of ancient human-climate-environment interrelationships is of growing interest in the context of global environmental change (Dearing, 2006) and requires development of new tools for enabling reconstruction of past environments and ecosystems, including past land use. Natural archives, such as sediments, but also soils, are reputed to retain the signature of past environmental settings. It is now recognised that, at least on a historical scale, land use change has an irreversible impact on soil in terms of bulk chemical properties and nutrient availability, as well as on the structure and patterns of surrounding vegetation communities (e.g. Peterken and Game, 1984; Dupouey et al., 2002; Prévosto et al., 2002; Hurtt et al., 2006; Fraterrigo et al., 2009). Among the different approaches developed to assess a past land use imprint in soil, the carbon isotopic composition of organic remains preserved in soil has been successfully applied for deciphering savanna grassland $\left(\mathrm{C}_{4}\right) \mathrm{vs}$. woodland $\left(\mathrm{C}_{3}\right)$ successions (Schwartz et al., 1986; Biedenbender et al., 2004; Bai et al., 2009, 2012). The rationale for the approach is that the $C$ isotopic composition of the soil organic matter (SOM) undergoes only limited change in the course of its evolution (Boutton, 1996; Bernoux et al, 1998; Boutton et al. 1998), and is reputedly stable on a geological timescale (Cerling et al., 1989). Unfortunately, the approach is generally not applicable to temperate habitats, where herbaceous plants and trees both use the $\mathrm{C} 3$ pathway.

While numerous studies have examined lipids and other molecular indicators of ancient land use in lacustrine sediments (e.g. Cranwell, 1984; Jacob et al., 2005; Fisher et al., 2003), little is known about the persistence of lipid imprints vs. time in soil (Jansen et al., 2008; Wiesenberg et al., 2010). The overwhelming majority of the studies of soil lipids aims to compare extant land use and molecular content (e.g. Otto and Simpson, 2005; van Bergen et al., 1997; Trendel et al., 2010). Only a few studies have examined the survival potential of soil lipids at the decadal (Wiesenberg et al., 2004) or even millennial scale (Huang et al., 1996). However, estimating the persistence of biomarker signatures in soil, and thus their residence time, is of crucial importance and could provide key information applicable to the analysis of molecular biomarkers preserved in lacustrine sediment records frequently used to track the changes of palaeoenvironmental conditions in the catchment. In this respect, it is important to know whether the studied signal corresponds to an instantaneous snapshot of the catchment, or covers a longer period of time and therefore has the potential to provide information about past land use. 
In the present study, we have compared the neutral lipid content of three profiles in soils which differ in their present and/or past use. The soils were sampled in the Lake Aydat catchment (Massif Central, France), an area that has undergone profound land use change in the last few decades and is presently covered by only two contrasting types of vegetation: grassland/pasture and forest (mainly coniferous; see Section 2.1). Accordingly, two of the selected soil profiles have remained under the same overlying vegetation (grass and conifers, respectively) at least for the last 60 years and were thus used as references. The third was covered with pasture/grassland up to 60 years ago and was then converted to a forest (mainly Picea sp.). The comparison of the three soil profiles allowed us to determine the molecular heritage from contrasted vegetation sources (grasses and conifers) and the potential of molecular biomarkers to survive in soil.

\section{Setting}

Lake Aydat is ca. $25 \mathrm{~km} \mathrm{SW}$ of Clermont-Ferrand, in the French Massif Central (Fig. 1). The small catchment (ca. $30 \mathrm{~km}^{2}$ ) which belongs to that of the River Loire, is at an altitude ranging from $837 \mathrm{~m}$ (lake level) to ca. 1,300 $\mathrm{m}$ above sea level, at the summit of the volcanoes of the Chaîne des Puys.

Located in a mountainous region of medium height, the catchment is subject to a harsh climate. The climatic uniformity and geological uniformity result in similar pedogenesis in the whole area. Andisols constitute the typical type of soil covering the catchment. From a general point of view, the soil developed mainly on a basaltic substratum, and is characterised by a high OM residence time (Dahlgren et al., 2004; Torn et al., 1997). In the catchment, the soil is rather thin (max. $30 \mathrm{~cm}$ depth), well drained and slightly acidic (Chambre d'Agriculture du Puy de Dôme, 2002).

\subsection{Recent land use history}

Until the middle of the $20^{\text {th }}$ century, self sufficiency in the region resulted in agricultural landscapes shared between cereal and vegetable farming, and animal breeding, under tough natural conditions requiring traditional production methods (Michelin, 1996). Severe land use change intervened just after the Second World War when intensification and specialisation of agriculture in producing basins affected the whole of France. Combined with industrial and urban development, these historical changes triggered a rural exodus (Bazin et al., 1983; Prévosto et al., 2002). The favourable climate of the region then allowed intensive reforestation, initiated to address the increasing demand for wood in the European market and 
to slow down the advance of abandoned land (Gadant, 1968). At present, most of the catchment is covered by unploughed grassland (pasture and meadows; Michelin, 1996) and, to a lesser extent, by shrubs that developed on former grazing plots. The top of the volcanic mountains is covered by forest (generally artificial coniferous forests, mostly of Picea sp.).

\section{Material and methods}

\subsection{Sampling}

The present work was undertaken as part of a larger study for which 35 soil cores, representative of the diversity of soil occupation and different topographical conditions (orientation, slope...), had been sampled in the Lake Aydat catchment in the fall of 2008. Old aerial pictures revealed that most of the sampling sites were converted from crop farming to grassland/pasture < 60 years ago or were already being used as grassland/pastures at the time. The lack of knowledge about reliable molecular biomarkers of ancient farming activity and the absence of such a land use on the catchment at present prompted us to focus on conversion of grassland/pasture to conifer forest (the reverse - former forest transformed to grassland was not taken into consideration because it does not apply to the catchment).

On the basis of these premises and, following preliminary analysis, 3 representative cores were selected to assess the impact of land use change on the soil lipid composition. The main characteristics of the samples are summarized in Table 1. Their past land use was assessed from aerial pictures taken in 1946. Soil $\mathrm{Sp}$ (16 cm thick) and soil $\mathrm{Sf}(22 \mathrm{~cm})$, that have been occupied by a pasture and a coniferous forest, respectively, for $>60$ years were taken as references for the two types of environment. In contrast, sample Spf $(14 \mathrm{~cm})$ was taken from a forest (covered mainly by conifers and very similar to Sf), that was formerly (i.e. $60 \mathrm{yr}$ ago) a pasture. The slope calculated for the soil under pasture is moderate $\left(5.7^{\circ}\right)$, and higher for the current forest $\left(11.0^{\circ}\right.$ for Spf, $14.9^{\circ}$ for Sf) located on the hillside of the "Puy de la Rodde" volcano (Fig. 1). Visual observation showed that the organo-mineral horizon A, of sand-silt constitution, was the only recognizable one above the $\mathrm{C}$ horizon out of the humus, in sharp contrast to the subjacent horizon in the forest samples. This organic horizon was ca. 6 $\mathrm{cm}$ and $8 \mathrm{~cm}$ thick in the Spf and Sf soil profiles, respectively.

\subsection{Lipid analysis}

Since a single organo-mineral horizon (A), accompanied by the humus in the forest soil, could be distinguished, soil monoliths were sub-sampled in $2 \mathrm{~cm}$ slices. Sub-samples were dried at $40{ }^{\circ} \mathrm{C}$ over $48 \mathrm{~h}$ in an oven, crushed in a mortar and sieved at $2 \mathrm{~mm}$. 
An aliquot (ca. $2 \mathrm{~g}$ ) of each sample was extracted by way of automatic solvent extraction with a Dionex® ASE 200 using a mixture of $\mathrm{CH}_{2} \mathrm{Cl}_{2}: \mathrm{MeOH}(1: 1 \mathrm{v} / \mathrm{v})$. After removal of the solvent under $\mathrm{N}_{2}$, the extract was separated into neutral, acidic and polar fractions on aminopropyl-bonded silica, as described by Jacob et al. (2005). The neutral fraction was separated into aliphatics, aromatics, ethers + esters, ketones + acetates, and alcohols by way of flash chromatography with a Pasteur pipette filled with activated silica (24 $\mathrm{h}$ at $120{ }^{\circ} \mathrm{C}$, then deactivated with $5 \% \mathrm{H}_{2} \mathrm{O}$ ), using a sequence of solvents of increasing polarity. Gas chromatography-mass spectrometry (GC-MS) utilised a Thermo® TRACEGCQ Polaris. The GC instrument was fitted with a Rtx-5MS column (30 m x $0.25 \mathrm{~mm}$ i.d., $0.25 \mu \mathrm{m}$ film thickness; $5 \mathrm{~m}$ column guard). The GC operating conditions were: $40^{\circ} \mathrm{C}(1$ min) to $120{ }^{\circ} \mathrm{C}$ at $30{ }^{\circ} \mathrm{C} \cdot \mathrm{min}^{-1}$, then to $300{ }^{\circ} \mathrm{C}$ (held $30 \mathrm{~min}$ ) at $5^{\circ} \mathrm{C} \cdot \mathrm{min}^{-1}$. Samples were injected in splitless mode, with the injector at $280{ }^{\circ} \mathrm{C}$. He was the carrier gas at a constant 1 $\mathrm{ml} \mathrm{min}{ }^{-1}$. The mass spectrometer was operated in the electron ionization (EI) mode at $70 \mathrm{eV}$ and scanned from $\mathrm{m} / \mathrm{z} 50$ to 600 . Compounds were assigned by comparison with authentic standards and/or literature mass spectral data reported by Lavrieux (2011), Lavrieux et al. (2011) and Le Milbeau et al. (2011).

\section{3. pH, granulometry and Rock-Eval pyrolysis}

Details of soil $\mathrm{pH}$, granulometry and $\mathrm{OM}$ quantitation and characterisation via RockEval pyrolysis [i.e. mainly total organic carbon (TOC, \%), hydrogen index and oxygen index ( $\mathrm{HI}$ and $\mathrm{OI}$ in mg hydrocarbons $\mathrm{gTOC}^{-1}$ and $\mathrm{CO}_{2} \mathrm{gTOC}^{-1}$, respectively)] were presented by Zocatelli et al. (2012), so only those relevant here are mentioned below.

\section{Results and discussion}

\subsection{Bulk analysis}

As generally observed (e.g. Marseille et al., 1995; Disnar et al., 2003), TOC decreases with depth in the three profiles here (Fig. 2; Table 1). The profiles are rich in OM, independently of their vegetation cover, varying from 10-18\% at the surface (Sp and Spf, respectively) to $4-5.5 \%$ at $12-14 \mathrm{~cm}$ (Spf - Sf, and Sp respectively). The TOC of the thickest profile (Sf) stabilized at ca. $2.4 \%$ down to the base $(20-22 \mathrm{~cm})$. The decrease was progressive for the grassland soil, whereas the two forest soil profiles were affected by an increase in TOC just below the humus.

HI values (Fig. 2, Table 1) also generally decreased with depth, but not linearly with TOC, and again in a two phase trend for Sf and Spf. Values ranged from 239-278 mg HC g 
$\mathrm{TOC}^{-1}$ (Sf and Spf, respectively) at the top to $152-187 \mathrm{mg} \mathrm{HC} \mathrm{g} \mathrm{TOC}^{-1}$ at $12-14 \mathrm{~cm}$ (Spf and $\mathrm{Sp}$, respectively). A lower value of $114 \mathrm{mg} \mathrm{HC} \cdot \mathrm{gTOC}^{-1}$ was reached in the deepest Sf level.

In the three profiles, OI values increased regularly with depth (from 186 at the top to 220-259 $\mathrm{mg} \mathrm{CO}_{2} \mathrm{~g} \mathrm{TOC}^{-1}$ at $12-14 \mathrm{~cm}$ and up to $271 \mathrm{mg} \mathrm{CO}_{2} \mathrm{~g} \mathrm{TOC}^{-1}$ at the bottom of $\mathrm{Sf}$ ), except for Sf where the 2-4 cm depth slice was in sharp contrast with the otherwise progressive trend in the parameter.

The reliability of the information conveyed by molecular biomarkers relies on the qualitative and quantitative preservation of the OM in soil profiles, which is supposed to be high in andisols (Section 2) and which is confirmed by bulk OM analysis. Here, the TOC richness of all the samples attests to a long SOM residence time, and thus to good OM preservation. This rough appraisal was reinforced by the complete absence of aromatic compounds observed in a previous study of the same samples (Lavrieux, 2011), pointing to a well preserved lipid content (Spyckerelle, 1975).

HI values of the sub-surface samples $(2-4 \mathrm{~cm})$ were similar to those of other samples from the catchment (Zocatelli et al., 2012), but were quite low when compared with the large soil sample set studied by Disnar et al. (2003). However, as pointed out by the latter authors, HI values are largely dependent on local vegetation. The progressive HI decrease with increasing depth in the profiles and the associated OI increase clearly depict a general tendency towards further oxidation, affecting the SOM in the profiles, together with the increase in humification and mineralization (Disnar et al., 2003). The 2-4 cm section of the forest soil Sf was rather unusual. Particularly high OI values reflected an advanced state of oxidation, i.e. a rather low degree of OM preservation. This is consistent with a previous analysis of this sample which revealed a high content of free fatty acids (FAs) indicative of a release of these compounds by hydrolysis of plant esters (Zocatelli et al., 2012). Comparison of Sf and Spf showed that the latter displayed a higher TOC value associated with a lower $\mathrm{pH}$. According to Prévosto et al. (2002), who worked on soil samples sampled from the north of Aydat catchment - including one located on the northside of the Puy de la Rodde near the site where Sf and Spf were taken (Fig. 1) - this tendency is typical of current forest soil known as ancient heath. If one assumes that the observation can be applied to the case of a conversion from grassland to forest, this could explain the differences observed between Spf and Sf.

\subsection{Lipid content}

The main families detected in the neutral lipids included well known and well studied families such as $n$-alkanes and $n$-alkan-2-ones, FA methyl esters (FAMEs), steroids and 
tricyclic diterpenes and their oxygenated derivatives, as well as triterpenoids such as the recently described methoxyserratenes (Le Milbeau et al., 2011) and triterpenyl acetates (Lavrieux et al., 2011).

The greatest part of the soil lipids originates directly from the local vegetation (van Bergen et al., 1997). However, in the sub-soil the composition of SOM can also be strongly affected by pedogenetic processes (Rumpel et al., 2002). Assuming that the three sampled soils underwent the same pedogenesis, then differences in the composition of the surrounding vegetation largely explain, to a first approximation, variation in the lipid composition. This assumes that the variation in biomarker concentration along the profiles is not controlled by selective component degradation.

A general overview of the lipid content of Spf showed that it was qualitatively uniform along the profile, the main differences lying in the relative proportions of individual compounds. This overall homogeneity is exemplified in Fig. 3, which shows the distribution of ketones/acetates from non-adjacent soil slices (2-4 cm and 10-12 cm).

\subsubsection{Forest biomarkers}

\subsubsection{Tricyclic diterpenoids and oxygenated tricyclic diterpenoids}

Tricyclic diterpenoid hydrocarbons (and oxygenated derivatives), well known as conifer products (e.g. Otto and Wilde, 2001 and references therein; Stefanova et al., 2002 and references therein), were totally absent from the grassland soil Sp. Eight tricyclic diterpenes were found in Sf and Spf in similar proportions (Fig. 4). Oxygenated tricyclic diterpenes, that are more numerous in Sf (18 components) than in Spf (13 components), suggested either slight differences in the local plant source(s) or a more diluted content in Spf that did not allow detection of all the compounds, some being either absent or only present at too low a level to be detected. An alternative hypothesis would be that the lower component concentrations resulted from lower accumulation of tricyclic diterpenes as a consequence of a shorter conifer coverage time.

\subsubsection{Methoxyserratenes}

Compounds belonging to the methoxyserratene family are highly specific to conifers

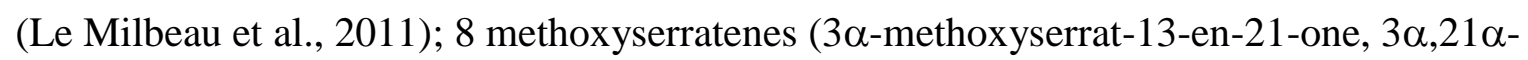
dimethoxyserrat-14-ene, 21 $\beta$-methoxyserrat-14-en-3-one, 3-methoxyserrat-14-en-21-one, $21 \alpha$-methoxyserrat-14-en-3-one, 3-methoxyserrat-14-en-21 $\alpha$-yle acetate, $3 \alpha$-methoxyserrat- 


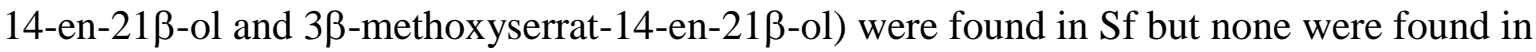
the grassland soil Sp. These compounds were also present in the Spf profile, but usually in trace amounts, even at the top of the profile (Fig. 4). This might result from the short time of OM accumulation, especially for the bottom levels of the profile.

\subsubsection{Grassland biomarkers}

\subsubsection{Wax esters}

Consistent with previous observations whereby wax esters appear specific to grassland soil in the Aydat catchment (Lavrieux, 2011), members of this family were detected only in the grassland soil Sp but not in the forest profile Sf. They were also absent from the Spf profile, which showed a more typical forest imprint. Their absence can be explained by their more rapid hydrolysis in the forest soil than in grassland, under the more acidic conditions (Otto and Simpson, 2005; Lavrieux, 2011). It can thus be hypothesized that in Spf, the conversion to forest rapidly led to conditions that favoured rapid hydrolysis of the wax esters.

\subsubsection{Triterpenyl acetates}

Bauerenyl, isobauerenyl, lupeyl, taraxasteryl, $\psi$-taraxasteryl, swertenyl, pichierenyl, isopichierenyl and gammacerenyl acetates, previously defined as specific markers for Asteraceae (Lavrieux et al., 2011), were all present in variable proportion in Sp (grassland); their cumulated proportion ranged from ca. $0.7 \mu \mathrm{g} / \mathrm{g}$ TOC to ca. $4 \mu \mathrm{g} / \mathrm{g}$ TOC (Figs. 4 and 5). They were totally absent from the forest soil Sf. Soil Spf contained five of them (bauerenyl, lupeyl, isobauerenyl, $\psi$-taraxasteryl and swertenyl acetates; Fig. 5), at a cumulative concentration ranging from ca. 0.025 at the top to ca. $0.5 \mu \mathrm{g} / \mathrm{g}$ TOC towards the bottom of the profile, the concentration not being significantly different from that of the same compounds in $\mathrm{Sp}$. The absence of four compounds could be explained by selective degradation of some of the triterpenyl acetates but, as underlined by Lavrieux et al. (2011), the possibility of rearrangement of the compounds remains uncertain, and in the absence of such evidence, they can be considered as stable. In this hypothesis, the different compound diversity in Sp and Spf can most probably be explained, at least for the greatest part, by way of differences in plant source input. Pichierenyl, isopichierenyl and gammacerenyl acetates were totally absent from Spf, while swertenyl acetate was only barely detected at 6-8 $\mathrm{cm}$ depth. The four compounds were present throughout the Sp profile and in relatively high concentration for the former three. Lavrieux et al. (2011) underlined the high specificity of these four triterpenyl acetates, 
which they attributed solely to Picris hieracioides (hawkweed ox tongue). Accordingly, their almost total absence from Spf - while other compounds comparatively less concentrated in $\mathrm{Sp}$, such as bauerenyl, lupeyl and isobauerenyl acetates, were detected in Spf - allows us to hypothesize that (i) during grassland use, hawkweed ox tongue was probably nearly absent from the plot, and that (ii) as stated above, swertenyl acetate may also be produced by other species that do not produce pichierenyl, isopichierenyl and gammacerenyl acetates. Conversely, taraxasteryl acetate is synthesized by numerous species living in the catchment (Lavrieux et al., 2011). Considering its low concentration in Sp (Fig. 5), it could also be present in Spf but below the detection limit. So, the Asteraceae imprint in Spf is explained here by its previous land use as grassland. The increase in compound concentration (normalized to TOC) vs. depth, could be related here to the progressive input of fresh conifer material at the top of the profile, that dilutes the former grassland signal into the new forest one.

\subsubsection{Steroids}

Various steroidal ketones and alcohols were detected in the three profiles. Steroids are present in all eukaryote cells, but some are more specifically produced by microorganisms in the environment or even much more efficiently in the digestive track of animals (Bull et al., 2002). Accordingly, different steroid ratios have been proposed to assess faecal pollution (e.g. Jardé et al., 2007; Tyagi et al., 2008). The faecal marker contribution to Aydat soils was estimated from the following ratio (Lavrieux, 2011):

$$
\frac{\text { coprostanol }+ \text { epi - coprostanol }+ \text { stigmastanol }+ \text { epi }- \text { stigmastanol }+ \text { campestanol }}{\text { camp esterol }+ \text { sitosterol }+ \text { cholesterol }}
$$

The high value of the ratio (ca. 0.8) at the top of Sp was a factor of 4 lower at the bottom of the profile (Fig. 6). In contrast, the pattern of the ratio was not linear in Sf where, in addition, the higher values were ca. 25 and 90 times lower than the lowest and highest values encountered in Sp, respectively. In soil Spf the ratios were low, but always higher than those in Sf. These values increased significantly with depth, indicating a greater faecal contribution at the bottom of the profile, which is fully consistent with its past pasture land use.

\subsection{3. n-Alkyl compounds}

\subsubsection{1. n-Alkanes and n-alkan-2-ones}

$n$-Alkanes and also $n$-alkan-2-ones, assumed to be their $\beta$-oxidation products in Aydat catchment soils, (Lavrieux, 2011), as hypothesized by Amblès et al. (1993), ranged from $n$ - 
$\mathrm{C}_{15}$ to $n-\mathrm{C}_{35}$ in the $\mathrm{Sp}$ and $\mathrm{Sf}$ profiles, with, in both cases, a strong odd/even predominance characteristic of higher plants (Eglinton and Hamilton, 1967). In contrast, in soil Spf $n-\mathrm{C}_{34}$ and $n-\mathrm{C}_{35}$ were not detected below $8 \mathrm{~cm}$. For both families, $n-\mathrm{C}_{29}$ and $n-\mathrm{C}_{31}$ are the major homologues for Sf and Sp, respectively, consistent with their plant source (Cranwell, 1973; van Bergen et al., 1997). Indeed the $n-\mathrm{C}_{29} / n-\mathrm{C}_{31}$ alkane values (Fig. 7) remained $<0.8$ throughout the grassland profile $\mathrm{Sp}$, whereas the forest soil $\mathrm{Sf}$ showed values $>1.6$. The $n$ $\mathrm{C}_{29} / n-\mathrm{C}_{31}$ alkan-2-one values (Fig. 7) were quite similar to those of the $n$ - $\mathrm{C}_{29} / n$ - $\mathrm{C}_{31} n$-alkane values, except in the Sf topsoil where much higher values (ca. $4 \mathrm{x}$ ) were observed. This is fully consistent with the oxidation that affected the upper levels of this profile, as mentioned above. For the two compound families, the Spf profile showed intermediate values - i.e. always ca. 1 - which does not allow delineating any trend from one pool to the other. This could be explained by variable plant input, or variable environmental conditions, these two factors having a strong influence on the $n$-alkane signature (Cranwell, 1973; Kerfourn and Garrec, 1992; Marseille et al., 1999). However, the proximity of the Spf and Sf sampling sites is not in favour of the second hypothesis; with $n-\mathrm{C}_{29}$ and $n-\mathrm{C}_{31}$ being produced both by trees and grass although in different proportions, the accumulation of grassland and forest signals in Spf could have led to an averaging of the ratio values by mixing, probably favoured by root penetration into the profile.

\subsubsection{FAMEs}

In the literature, FAMEs usually designate FAs that were either initially free in a sample or released from a bound form via hydrolysis, and subsequently methylated for analytical purposes. At Aydat, such esters that were also found among the neutral soil lipids without any methylation treatment (Lavrieux, 2011) were thus assumed to be natural, as described by Grasset and Amblès (1998).

The three soils displayed bimodal FAME distributions extending from $n-\mathrm{C}_{14: 0}\left(\mathrm{C}_{\min }\right)$ to $n-\mathrm{C}_{32: 0}\left(\mathrm{C}_{\max }\right)$ with a marked even/odd predominance; $n-\mathrm{C}_{16: 0}$ and $n-\mathrm{C}_{26: 0}$ or $n-\mathrm{C}_{24: 0}$ were the dominant compounds throughout the profiles and did not allow any distinction between the two main types of vegetation; $n-\mathrm{C}_{16: 0}$ and $n-\mathrm{C}_{26: 0}$ were the two dominant compounds throughout the forest profile Sf but also in the upper $10 \mathrm{~cm}$ of the grassland soil $\mathrm{Sp}$. In contrast, a predominance of $n-\mathrm{C}_{16: 0}$ and $n-\mathrm{C}_{24: 0}$ was observed in the sections below $10 \mathrm{~cm}$ depth in Sp and also in the whole Spf profile. The origin of these two high molecular weight FAME modes remains conjectural.

Differences in microbial activity between grassland and forest could be much better revealed by iso- and anteiso- compounds of well documented microbial origin (Cooper and 
Blumer, 1968; Boon et al., 1977). In fact, $i \mathrm{C}_{15: 0}$ and $a i \mathrm{C}_{15: 0}$, described in earlier studies as bacterial markers (Cho and Salton, 1964; Boon et al., 1977) were detected along the 3 soil profiles. Comparison of the $\left(i \mathrm{C}_{15: 0}+a i \mathrm{C}_{15: 0}\right) / \mathrm{C}_{15: 0} \mathrm{FAME}$ ratio showed that the values (Fig. 8) ranged from 3.2 to 3.7 in the grassland soil $\mathrm{Sp}$, whereas they were clearly lower for the forest profile Sf (i.e. 2.1-2.3) as well as in the 8 upper $\mathrm{cm}$ of soil $\mathrm{Spf}$, covered by trees for a few decades. However, in the latter case, the values increased suddenly downward from $8 \mathrm{~cm}$ to reach values of 2.85-3.0, close to those of the grassland soil and thus in full agreement with the grassland inheritance of Spf. As for triterpenyl acetates, if one omits the different origin of the iso- and anteiso FAMEs (bacterial vs. inherited from vegetation in the case of triterpenyl acetates), the preferential accumulation of these latter compounds, that appear typical for grasslands at the base of the profile, can also, at least partly, be attributed to their accumulation at depth as a result of leaching or transport facilitated by root penetration.

\subsection{General discussion and conclusions}

To fill the lack of knowledge about the residence time of molecular biomarkers in soils, the neutral lipid content of three soil profiles with different land use history was studied. The generally good OM preservation attested to via bulk analysis indicated that degradation was probably not the major factor explaining the variations in the molecular content along the three soil profiles and between them. This was fully confirmed by several molecular indices for the Spf soil profile that changed use about 60 years ago.

Whereas the reference soils Sf and Sp had a lipid content unequivocally related to the current plant cover, whatever the depth, soil Spf showed a more mitigated imprint. In contrast to compounds such as $n$-alkanes, $n$-alkan-2-ones and wax esters, that failed to clearly distinguish the former land use from its current one, the imprint of the ancient land use was distinctly recorded via iso- and anteiso- $\mathrm{C}_{15: 0}$ FAMEs, tricyclic diterpenes and their oxygenated derivatives, triterpenes and steroids (indicating faecal contribution and characterizing cattle breeding areas).

The current use of Spf as a soil forest was well expressed by the occurrence of typical conifer markers (especially tricyclic diterpene hydrocarbons, their oxygenated derivatives and also methoxyserratenes). All these compounds were more concentrated in Spf humus, although their imprint was not as clearly recorded as in Sf in terms of component diversity (lack of several oxygenated tricyclic diterpenes) or component distribution with depth (lower concentration of methoxyserratenes in Spf than in Sf, even at the top of the profile). Conversely, the occurrence of unequivocal grassland markers such as triterpenyl acetates, 
accompanied by higher values of steroid and FAME ratios within the profile, particularly in the deepest samples, implied a lipid pattern that could be straightforwardly linked to its ancient grassland use. Although, from a qualitative basis, the lipid composition of Spf was not significantly different between the top and the bottom of the profile (Fig. 3), the concentrations of bauerenyl, isobauerenyl, lupeyl and $\psi$-taraxasteryl acetates in the bottom levels attested to a grassland signature (Figs. 3, 5, 6, 8).

Conversely, some molecular markers did delineate a sharp contrast between the two superimposed land use signatures. The settlement of forestry vegetation most probably rather rapidly brought about conditions favourable for the fast and complete hydrolysis of wax esters, a process that, within this hypothesis, could have been effective in less than 60 years. Although the $n$-alkane distribution mode has commonly been used in attempts at distinguishing herbaceous and lignin containing plant inputs (e.g. Cranwell, 1973; van Bergen et al., 1997), the present results show that the high molecular weight $n$-alkanes, as well as their $\beta$-oxidation products, $n$-alkan-2-ones, can no longer be considered as reliable for the distinction of plant inputs to a soil subjected to past land use change.

The classical picture supposing older SOM at the bottom of soil profiles could be discarded here because biomarkers of former land use were not strictly restricted to the deepest samples in Spf; in other words the Spf soil profile could not be simply divided in two parts, the upper part reflecting its current forest status and the base preserving its grassland history. The biomarker content of the whole profile appeared as an intimate mixture between components inherited from the past and current vegetation, more or less expressed following the family of compounds considered. This mixing might be explained initially by intensive bioturbation, probably associated with compound introduction at depth through leaching and conifer root penetration (Trendel et al., 2010).

The results open new insight into molecular biomarkers turnover time in soils, and show that the signal preserved differs according to the compounds considered: first if they are or not plant source specific, and also following their individual intrinsic stability. The distinction of vegetation type based on the occurrence or absence of (a) given compound(s) appears the most accurate since its removes any potential tendency of the environment to influence the concentration of the considered compounds, in marked contrast to the criteria that rely on relative compound abundances. In the light of these results, one must keep in mind that this overall behaviour would perhaps be expressed differently in deeper soils and/or in ones where different horizons could be clearly distinguished, thus underlining the need for further studies. 
Finally, if this case study brings new information about the survival capacity of lipid biomarkers in soils, it also raises questions about the reliability of the terrestrial signal recorded by lacustrine sediments. Indeed, if eroded soil material proves to contain a mixture of biomarkers reflecting current and past land use in the catchment, then to what extent is the signal archived in the lacustrine sediments biased by former catchment history, particularly in the case of high temporal resolution records?

\section{Acknowledgements}

The work received financial support from the ERODE project (EC2CO, CNRS/INSU) and the OTARIE project (Région Centre, European Council). M.L. also acknowledges the Région Centre for her PhD grant. We are grateful to P. Schaeffer and an anonymous reviewer for corrections and constructive comments.

\section{Associate Editor - J.K. Volkman}

\section{References}

Amblès, A., Jambu, P., Jacquesy, J.C., Parlanti, E., Secouet, B., 1993. Changes in the ketone portion of lipidic components during the decomposition of plant debris in a hydromorphic forest-podzol. Soil Science 156, 49-56.

Bai, E., Boutton, T.W., Liu, F., Wu, B., Archer, S.R. 2012. Spatial patterns of soil $\delta^{13}$ C reveal grassland-to-woodland successional processes. Organic Geochemistry 42, 1512-1518.

Bai, E., Boutton, T.W., Wu, X.B., Lieu, F., Archer, S.R., 2009. Landscape-scale vegetation dynamics inferred from spatial patterns of soil $\delta^{13} \mathrm{C}$ in a subtropical savanna parkland. Journal of Geophysical Research 114, G01019.

Bazin, G., Larrère, G.R., De Montard, F.X., Lafarge, M., Loiseau, P., 1983. Systèmes agraires et pratiques paysannes dans les Monts Dômes. INRA, Paris.

van Bergen, P.F., Bull, I.D., Poulton, P.R., Evershed, R.P., 1997. Organic geochemical studies of soils from the Rothamsted classical experiments. I - Total lipid extracts, solvent insoluble residues and humic acids from Broadbalk wilderness. Organic Geochemistry 26, 117-135.

Bernoux, M., Cerri, C.C., Neill, C., de Moraes, J.F.L., 1998. The use of stable carbon isotopes for estimating soil organic matter turnover rates. Geoderma 82, 43-58.

Biedenbender, S.H., McClaran, M.P., Quade, J., Weltz, M.A., 2004. Landscape patterns of vegetation change indicated by soil carbon isotope composition. Geoderma 119, 69-83.

Boon, J.J., de Leeuw, J.W., van den Hoek, G.J., Vosjan, J.H., 1977. Significance and taxonomic value of iso and anteiso monoenoic fatty acids and branched $\beta$-hydroxy acids in Desulfovibrio desulfuricans. Journal of Bacteriology 129, 1183-1191. 
Boutton, T.W., Archer, S.R., Midwood, A.J., Zitzer, S.F., Bol, R., 1998. $\delta^{13}$ C values of soil organic carbon and their use in documenting vegetation change in a subtropical savanna ecosystem. Geoderma 82, 5-41.

Boutton, T.W., 1996. Stable carbon isotope ratios of soil organic matter and their use as indicators of vegetation and climate change. In: Boutton, T.W., Yamasaki, S.I. (Eds.), Mass Spectrometry of Soils. Marcel Dekker, New York, pp. 47-82.

Bull, I.D., Lockheart, M.J., Elhmmali, M.M., Roberts, D.J., Evershed, R.P., 2002. The origin of faeces by means of biomarker detection. Environment International 27, 647-654.

Chambre d'Agriculture du Puy de Dôme, 2002. Contrat de Rivière Veyre - Monne - Lac d'Aydat. Etude de l'Agriculture. Document 1 : Présentation et pratiques agricoles. Syndicat Mixte de la Vallée de la Veyre, Saint-Saturnin.

Cho, K.Y., Salton, M.R.J., 1964. Fatty acid composition of the lipids of membranes of gram-positive bacteria and "walls" of gram-negative bacteria. Biochimica Biophysica Acta 84, 773-775.

Cerling, T.E., Quade, J., Wang, Y., Bowman, J.R., 1989. Carbon isotopes in soils and paleosols as ecology and paleoecology indicators. Nature 341, 138-139.

Cooper, W.J., Blumer, M., 1968. Linear, iso and anteiso fatty acids in Recent sediments of the North Atlantic. Deep Sea Research 15, 535-540.

Cranwell, P.A., 1984. Organic geochemistry of lacustrine sediments: Triterpenoids of higher-plant origin reflecting post-glacial vegetational succession. In: Haworth, E.Y., Lund, J.W.G. (Eds.), Lakes, Sediments and Environmental History. University Press, Leicester, pp. 69-92.

Cranwell, P.A., 1973. Chain-length distribution of n-alkanes from lake sediments in relation to postglacial environmental change. Freshwater Biology 3, 259-265.

Dahlgren, R.A., Saigusa, M., Ugolini, F.C., 2004. The nature, properties and management of volcanic soils. Advances in Agronomy 82, 113-182.

Dearing, J.A., 2006. Climate-human-environment interactions: resolving our past. Climate of the Past 2, 187-203.

Disnar, J.R., Guillet, B., Kéravis, D., Di Giovanni, C., Sebag, D., 2003. Soil organic matter (SOM) characterization by Rock-Eval pyrolysis: scope and limitations. Organic Geochemistry 34, 327-343.

Dupouey, J.L., Dambrine, E., Laffite, J.D., Moares, C., 2002. Irreversible impact of past land use onforest soils and biodiversity. Ecology 83, 2978-2984.

Eglinton, G., Hamilton, R.J., 1967. Leaf epicuticular waxes. Science 156, 1322-1335.

Fisher, E., Oldfield, F., Wake, R., Boyle, J., Appleby, P., Wolff, G.A., 2003. Molecular marker records of land-use change. Organic Geochemistry 34, 105-119.

Fraterrigo, J.M., Pearson, S.M., Turner, M.G., 2009. The response of understory herbaceous plants tonitrogen fertilization in forests of different land-use history. Forest Ecology and Management 257, 2182-2188. 
Gadant, J, 1968. Le reboisement en Auvergne. Revue Forestière Française 7/8, 449-457.

Grasset, L., Amblès, A., 1998. Aliphatic lipids released from a soil humin after enzymatic degradation of cellulose. Organic Geochemistry 29, 893-897.

Huang, Y.S., Bol, R., Harkness, D.D., Ineson, P., Eglinton, G., 1996. Post-glacial variations in distributions, ${ }^{13} \mathrm{C}$ and ${ }^{14} \mathrm{C}$ contents of aliphatic hydrocarbons and bulk organic matter in three types of British acid upland soils. Organic Geochemistry 24, 273-287.

Hurtt, G.C., Frolking, S., Fearon, M.G., Moore, B., Shevliakova, E., Malyshev, S., Pacala, S.W., Houghton, R.A., 2006. The underpinnings of land-use history: three centuries of global gridded land-use transitions, wood-harvest activity, and resulting secondary lands. Global Change Biology 12, 1208-1229.

Jacob, J., Disnar, J.R., Boussafir, M., Albuquerque, A.L.S., Sideffine, A., Turcq, B., 2005. Pentacyclic triterpene methyl ethers in recent lacustrine sediments (Lagoa do Caçó, Brazil). Organic Geochemistry 36, 449-461.

Jansen, B., Haussmann, N.S., Tonneijck, F.H., Verstraten, J.M., de Voogt, P., 2008. Characteristic straight-chain lipid ratios as a quick method to assess past forest-páramo transitions in the Ecuadorian Andes. Palaeogeography, Palaeoclimatology, Palaeoecology 262, 129-139.

Jardé, E., Gruau, G., Mansuy-Huault, L., Peu, P., Martinez, J., 2007. Using sterols to detect pig slurry contribution to soil organic matter. Water, Air \& Soil Pollution 178, 169-178.

Kerfourn, C., Garrec, J.P., 1992. Modifications in the alkane composition of the cuticular waxes from spruce needles (Picea abies) and ivy leaves (Hedera helix) exposed to ozone fumigation and acid fog. Comparison with needles from declining spruce trees. Canadian Journal of Botany 70, 861-869.

Lavrieux, M., 2011. Biomarqueurs moléculaires d'occupation des sols, du sol au sediment : exemple du bassin-versant et du lac d'Aydat (Puy-de-Dôme). Ph.D. thesis, University of Tours (France), $246 \mathrm{pp}$.

Lavrieux, M., Jacob, J., Le Milbeau, C., Zocatelli, R., Masuda, K ., Bréheret, J.G., Disnar, J.R., 2011. Occurrence of triterpenyl acetates in soil and their potential as chemotaxonomical markers of Asteraceae. Organic Geochemistry 42, 1315-1323.

Le Milbeau, C., Lavrieux, M., Jacob, J., Zocatelli, R., Disnar, J.R., 2011. Methoxy-serratenes as discriminant biomarkers for soils developed under conifer forests. Abstract. $25^{\text {th }}$ International Meeting on Organic Geochemistry, Interlaken, P-491. .

Marseille, F., Disnar, J.R., Guillet, B., Noack, Y., 1999. n-Alkanes and free fatty acids in humus and A1 horizons of soils under beech, spruce and grass in the Massif-Central (Mont-Lozère), France. European Journal of Soil Science 50, 433-441.

Michelin, Y., 1996. Les jardins de Vulcain : Paysages d'hier, d'aujourd'hui et de demain, dans la chaîne des Puys du Massif central français. Maison des Sciences de l’Homme, Paris. 
Otto, A., Simpson, M.J., 2005. Degradation and preservation of vascular plant-derived biomarkers in grassland and forest soils from Western Canada. Biogeochemistry 74, 377-409.

Otto, A., Wilde, V., 2001. Sesqui-, di-, and triterpenoids as chemosystematic markers in extant conifers - A review. The Botanical Review 67, 141-238.

Peterken, G.F., Game, M., 1984. Historical factors affecting the number and distribution of vascular plant species in the woodlands of central Lincolnshire. Journal of Ecology 72, 155-182.

Prévosto, B., Curt, T., Moares Domínguez, C., Dambrine, E., Poutier, F., Pollier, B., 2002. Soils in silver birch and scots pine natural woodlands on a mid-elevation volcanic mountain ( $\mathrm{La}$ Chaîne des Puys, French Massif Central). Influence of tephras chemistry and past land use, effects on vegetation composition. (Les sols sous boisements spontanés de bouleau et de pin sylvestre dans la Chaîne des Puys. Influence du substratum et de l'utilisation ancienne, conséquences sur la végétation). Etude et gestion des sols 9, 251-267.

Rumpel, C., Kögel-Knabner, I., Bruhn, F., 2002. Vertical distribution, age, and chemical composition of organic carbon in two forest soils of different pedogenesis. Organic Geochemistry 33, 1131-1142.

Schwartz, D., Mariotti, A., Lanfranchi, R.E., Guillet, B., 1986. ${ }^{13} \mathrm{C}^{12} \mathrm{C}$ ratios of soil organic matter as indicator of vegetation changes in the Congo. Geoderma 39, 97-103.

Spyckerelle, C., 1975. Constituants aromatiques de sédiments. PhD thesis, University Louis Pasteur de Strasbourg, $134 \mathrm{pp}$.

Stefanova, M., Oros, D.R., Otto, A., Simoneit, B.R.T., 2002. Polar aromatic biomarkers in the Miocene Maritza-East lignite, Bulgaria. Organic Geochemistry 33, 1079-1091.

Torn, M.S., Trumbore, S.E., Chadwick, O.A., Vitousek, P.M., Hendricks, D.M., 1997. Mineral control of soil organic carbon storage and turnover. Nature 389, 170-173.

Trendel, J.M., Schaeffer, P., Adam, P., Ertlen, D., Schwartz, D., 2010. Molecular characterization of soil surface horizons with different vegetation in the Vosges Massif (France). Organic Geochemistry 41, 1036-1039.

Tyagi, P., Edwards, D.R., Coyne, M.S., 2008. Use of sterol and bile acid biomarkers to identify domesticated animal sources of fecal pollution. Water, Air \& Soil Pollution 187, 263-274.

Wiesenberg, G.L.B., Dorodnikov, M., Kuzyakov, Y., 2010. Source determination of lipids in bulk soil and soil density fractions after four years of wheat cropping. Geoderma 156, 267-277.

Wiesenberg, G.L.B., Schwartzbauer, J., Schmidt, M.W.J., Schwark, I., 2004. Sources and turnover of organic matter in agricultural soils derived from $n$-alkane / $n$-carboxylic acid compositions and C-isotope signatures. Organic Geochemistry 35, 1371-1393.

Zocatelli, R., Lavrieux, M., Disnar, J-R., Le Milbeau, C., Jacob, J., Bréheret, J.G., 2012. Free fatty acids composition of soils developed under distinct vegetation cover in the catchment of Lake Aydat (Massif central, France). Journal of Soils and Sediments. DOI: 10.1007/s11368-0120505-1. 


\section{Figure captions}

Fig. 1. Location of Lake Aydat catchment with indication of current land use and sampling sites.

Fig. 2. TOC and HI vs. depth for the three soil cores. Solid black lines, Soil Sp; solid light grey lines, soil Sf; dotted dark grey lines, soil Spf.

Fig. 3. GC-MS traces of 2-4 cm and 10-12 cm slices for ketone/acetate fraction of soil profile Spf. The same quantity of standard (IS, $5 \alpha$-cholestane) was added to each fraction. Nomenclature of compounds after Lavrieux (2011). Oxygenated tricyclic diterpenes: ox2, abieta-8,11,13-trien-7-one; ox12, dehydroferruginol; ox18, 12-hydroxysimonellite; ox3, ox6, ox7, ox9, ox10, ox11, ox13, ox14 and ox17, unidentified compounds. Triterpenyl acetates: ta4, isobauerenyl acetate; ta7, lupeyl acetate; ta9, bauerenyl acetate; ta10, taraxasteryl acetate.

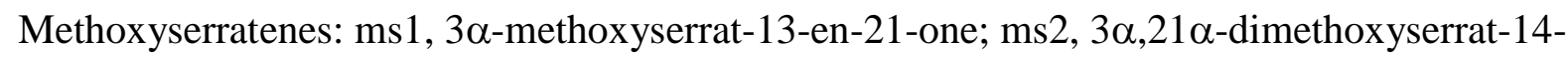
ene; ms3, 21 $\beta$-methoxyserrat-14-en-3-one; ms4, 3-methoxyserrat-14-en-21-one; ms5, $21 \alpha$ methoxyserrat-14-en-3-one.

Fig. 4. Occurrence of forest biomarkers (tricyclic diterpenes, oxygenated tricyclic diterpenes, methoxyserratenes) and grassland biomarkers (triterpenyl acetates) in the three soil profiles. Nomenclature after Lavrieux (2011). Tricyclic diterpenes: DT1, DT4, DT6, norabietadiene isomers; DT2, DT3, DT5, DT8, abietadiene isomers; DT7, DT10, 19(18)-norabieta- 8,11,13triene isomers; DT9, 18(19)-norabieta-4(19),8,11,13-tetraene; DT11, dehydroabietane. Oxygenated tricyclic diterpenes: ox2, abieta-8,11,13-trien-7-one; ox 12, dehydroferruginol; ox18, 12-hydroxysimonellite; ox1, ox3-ox11, ox13-ox17, unidentified compounds.

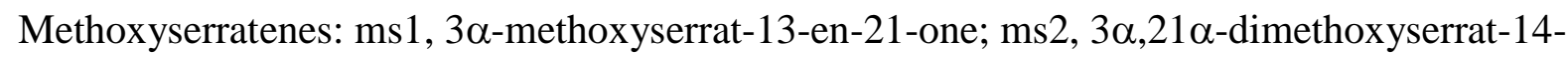
ene; ms3, 21 $\beta$-methoxyserrat-14-en-3-one; ms4, 3-methoxyserrat-14-en-21-one; ms5, $21 \alpha$ methoxyserrat-14-en-3-one; ms6, 3-methoxyserrat-14-en-21 $\alpha$-yle acetate; ms7, $3 \alpha$ methoxyserrat-14-en-21 $\beta$-ol; ms8, 3 $\beta$-methoxyserrat-14-en-21 $\beta$-ol. Triterpenyl acetates: ta4, isobauerenyl acetate; ta7, lupeyl acetate; ta9, bauerenyl acetate; ta10, taraxasteryl acetate; ta11, $\psi$-taraxasteryl acetate; ta12, isopichierenyl acetate; ta13, pichierenyl acetate; ta14, gammacerenyl acetate; ta15, swertenyl acetate. 
Fig. 5. Quantitation of specific triterpenyl acetates (Lavrieux et al., 2011) in Sp and Spf profiles. Concentration, $\mu \mathrm{g} / \mathrm{g}$ TOC.

Fig. 6. Depth profile of ratio of steroids expressing faecal contribution to the three soil profiles.

Fig. 7. Depth profile of (a) $n-\mathrm{C}_{29} / n-\mathrm{C}_{31}$ alkane ratio and (b) $n-\mathrm{C}_{29} / n-\mathrm{C}_{31} n$-alkan-2-one ratio.

Fig. 8. Depth profile of $\left(i \mathrm{C}_{15: 0}+a i \mathrm{C}_{15: 0}\right) / n-\mathrm{C}_{15: 0} \mathrm{FAME}$ ratio. 
Table 1

Main characteristics of the soil samples. ${ }^{\text {a }}$

\begin{tabular}{|c|c|c|c|c|c|c|c|c|c|c|}
\hline $\begin{array}{c}\text { Soil } \\
\text { monolith }\end{array}$ & $\begin{array}{l}\text { Depth of } \\
\text { profile }(\mathrm{cm})\end{array}$ & Slope $\left(^{\circ}\right)$ & $\begin{array}{l}\text { Slice depth } \\
\quad(\mathrm{cm})\end{array}$ & $\begin{array}{l}\text { TOC } \\
\text { (wt.\%) }\end{array}$ & $\mathrm{HI}$ & Ol & $\mathrm{pHCaCl}_{2}$ & Substratum & $\begin{array}{l}\text { Current } \\
\text { land use }\end{array}$ & $\begin{array}{l}\text { Past land use } \\
\text { (1946) }\end{array}$ \\
\hline \multirow{8}{*}{ Sp } & \multirow{8}{*}{16} & \multirow{8}{*}{5.7} & $0-2$ & 10.4 & 273 & 186 & \multirow{8}{*}{5.76} & \multirow{8}{*}{ Basaltic } & \multirow{8}{*}{ Pasture } & \multirow{8}{*}{ Pasture } \\
\hline & & & $2-4$ & 9.4 & 248 & 192 & & & & \\
\hline & & & $4-6$ & 9.0 & 244 & 199 & & & & \\
\hline & & & $6-8$ & 7.4 & 221 & 204 & & & & \\
\hline & & & $8-10$ & 6.5 & 211 & 214 & & & & \\
\hline & & & $10-12$ & 5.3 & 191 & 222 & & & & \\
\hline & & & $12-14$ & 5.4 & 187 & 220 & & & & \\
\hline & & & $14-16$ & 5.7 & 168 & 232 & & & & \\
\hline \multirow{7}{*}{ Spf } & \multirow{7}{*}{14} & \multirow{7}{*}{11.0} & $0-2$ & 18.2 & 278 & 186 & \multirow{7}{*}{5.2} & \multirow{7}{*}{$\begin{array}{c}\text { Basaltic } \\
\text { (on a } \\
\text { volcano) }\end{array}$} & \multirow{7}{*}{$\begin{array}{c}\text { Forest (Coniferous } \\
+ \text { Ferns } \\
+ \text { a few deciduous } \\
\text { trees and herbs) }\end{array}$} & \multirow{7}{*}{ Pasture } \\
\hline & & & $2-4$ & 10.8 & 232 & 211 & & & & \\
\hline & & & $4-6$ & 6.7 & 231 & 210 & & & & \\
\hline & & & $6-8$ & 8,7 & 221 & 210 & & & & \\
\hline & & & $8-10$ & 5.3 & 184 & 231 & & & & \\
\hline & & & $10-12$ & 4.1 & 165 & 239 & & & & \\
\hline & & & $12-14$ & 4.0 & 152 & 259 & & & & \\
\hline \multirow{11}{*}{ Sf } & \multirow{11}{*}{22} & \multirow{11}{*}{14.9} & $0-2$ & 12.3 & 239 & 187 & \multirow{11}{*}{5.5} & \multirow{11}{*}{$\begin{array}{l}\text { Basaltic } \\
\text { (on a } \\
\text { volcano) }\end{array}$} & \multirow{11}{*}{$\begin{array}{c}\text { Forest (Coniferous } \\
+ \text { Ferns } \\
+ \text { a few deciduous } \\
\text { trees and herbs) }\end{array}$} & \multirow{11}{*}{ Forest } \\
\hline & & & $2-4$ & 10.6 & 220 & 378 & & & & \\
\hline & & & $4-6$ & 6.7 & 194 & 218 & & & & \\
\hline & & & $6-8$ & 4.6 & 205 & 200 & & & & \\
\hline & & & $8-10$ & 5.7 & 225 & 201 & & & & \\
\hline & & & $10-12$ & 4.3 & 176 & 222 & & & & \\
\hline & & & $12-14$ & 4.0 & 158 & 253 & & & & \\
\hline & & & $14-16$ & 3.3 & 141 & 246 & & & & \\
\hline & & & $16-18$ & 3.0 & 140 & 263 & & & & \\
\hline & & & $18-20$ & 2.7 & 132 & 263 & & & & \\
\hline & & & $20-22$ & 2.4 & 114 & 271 & & & & \\
\hline
\end{tabular}

${ }^{\mathrm{a}} \mathrm{TOC}$, total organic carbon; HI, hydrogen index (mg hydrocarbon $\mathrm{g} \mathrm{TOC}{ }^{-1}$, standard deviation $\pm 6 \%$; OI, oxygen index $\left(\mathrm{CO}_{2} \mathrm{~g} \mathrm{TOC}^{-1}\right.$, standard deviation $\left.\pm 10 \%\right)$; standard deviations after Disnar et al., 2003; $\mathrm{pH}_{\mathrm{CaCl}} 2$ after Zocatelli et al., 2012. 
Figure 1
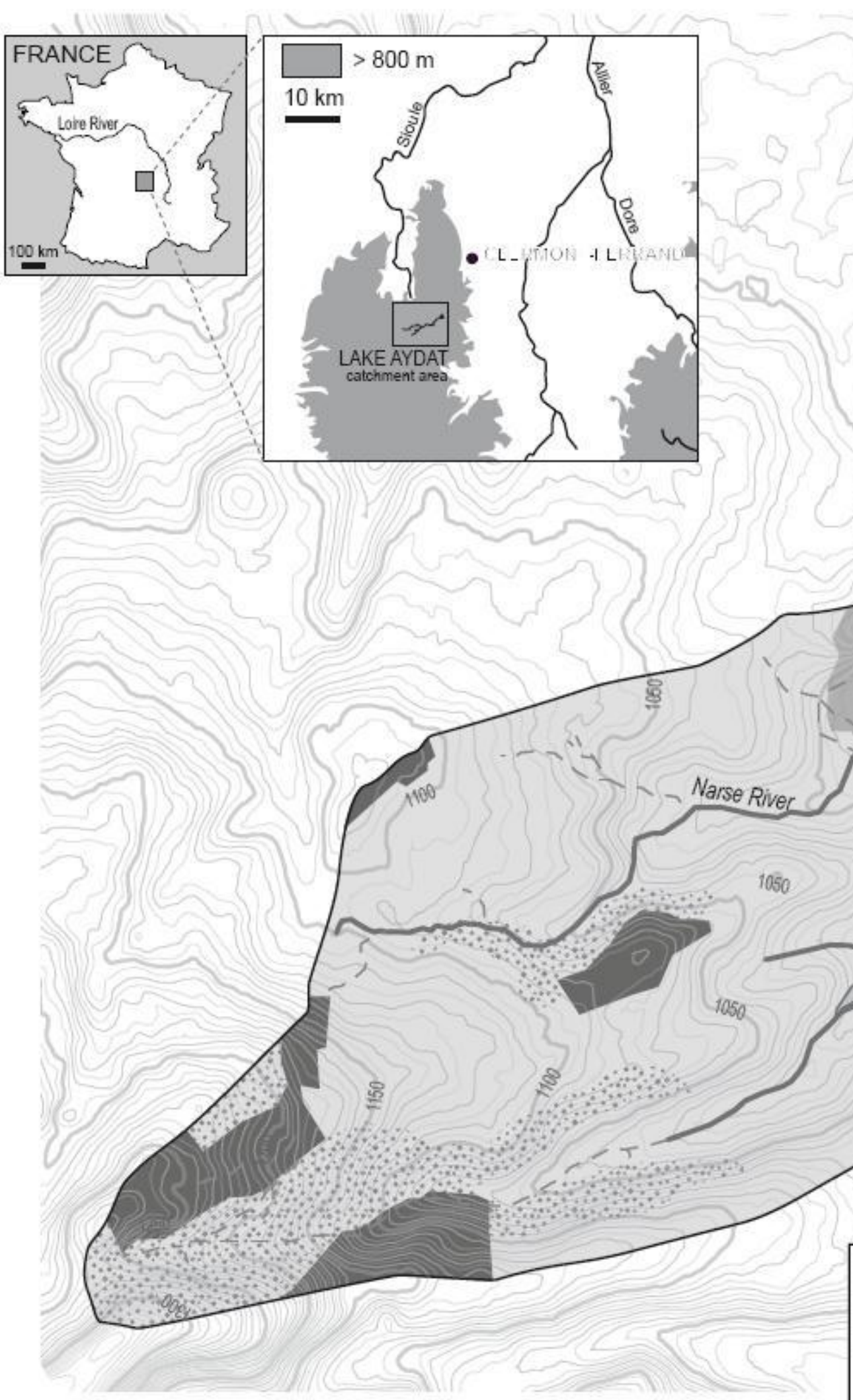

Landuse

Urbani

Grassla

Mixed

Conife

:-6." Fallow 

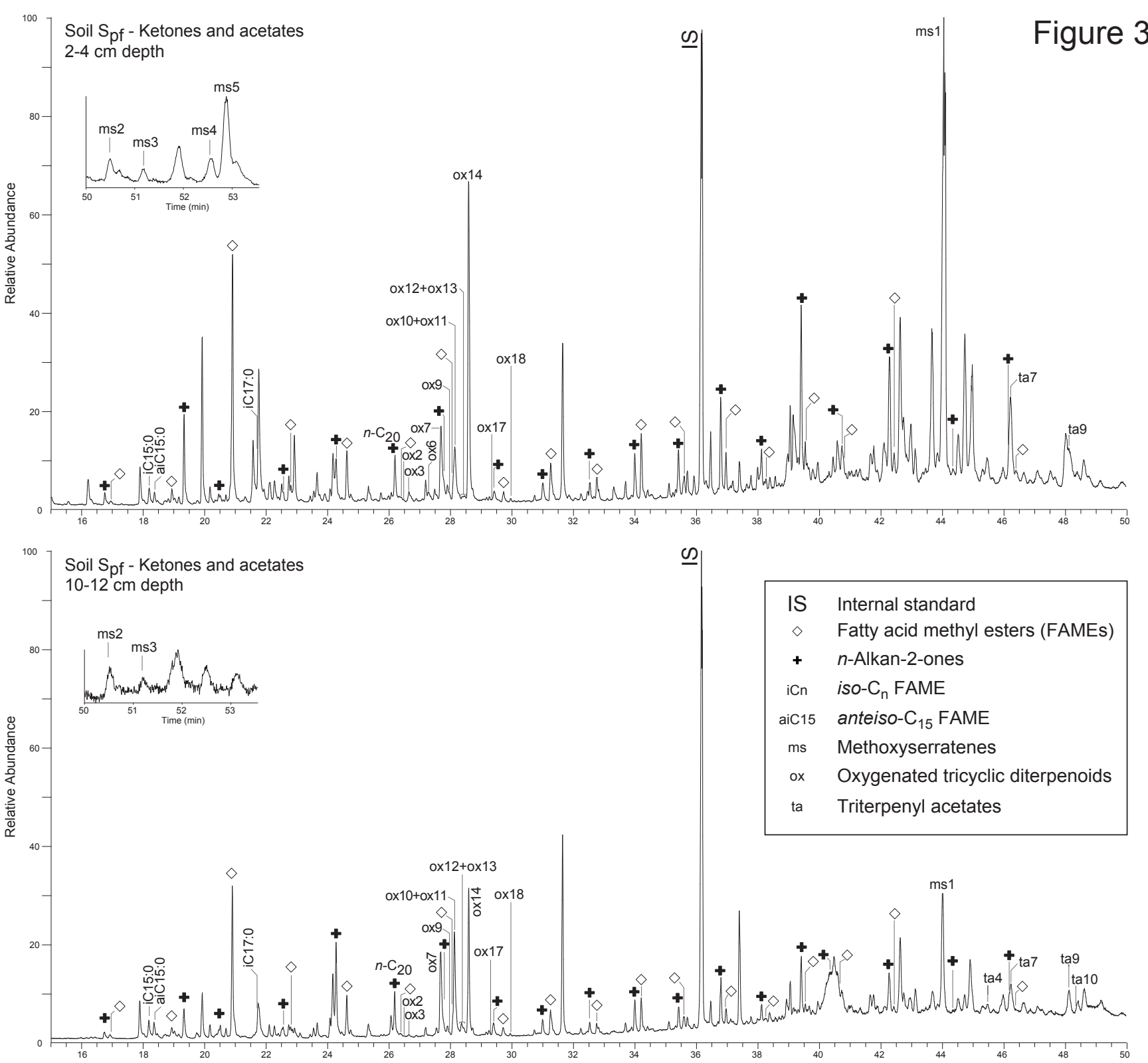
Figure 5

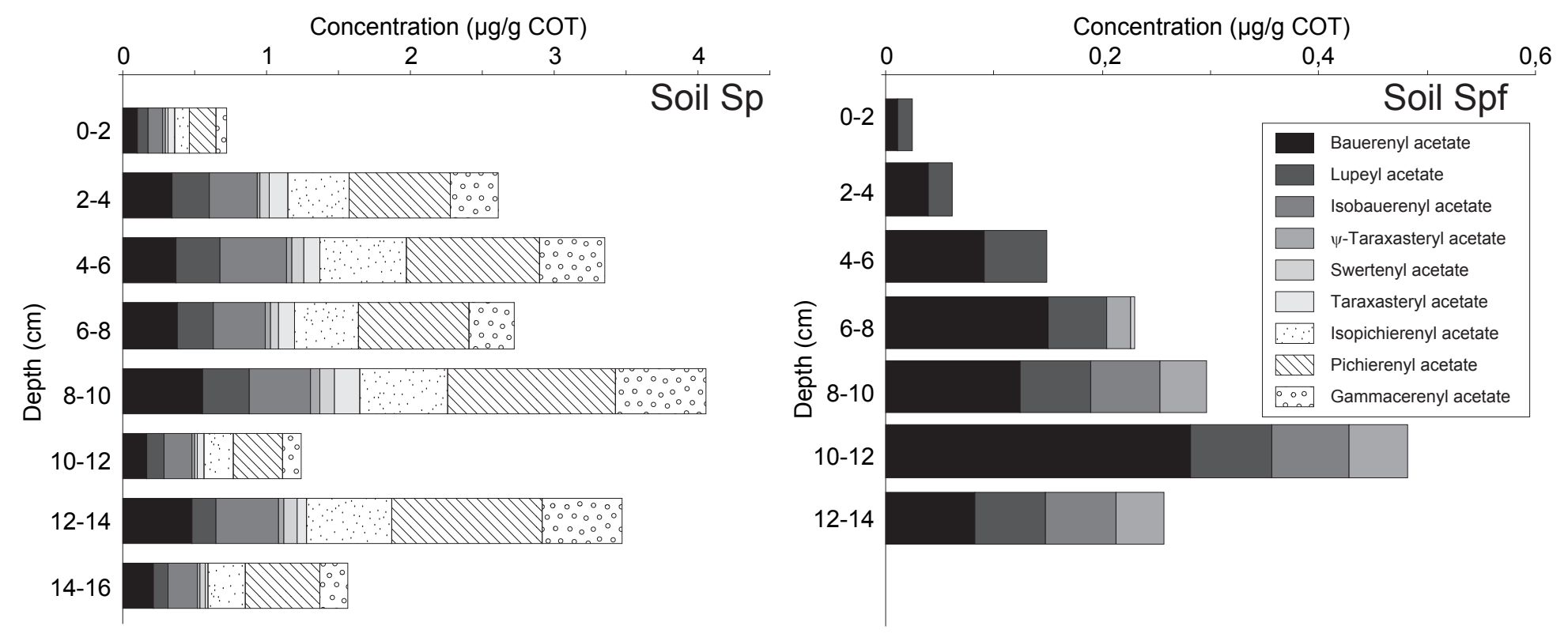



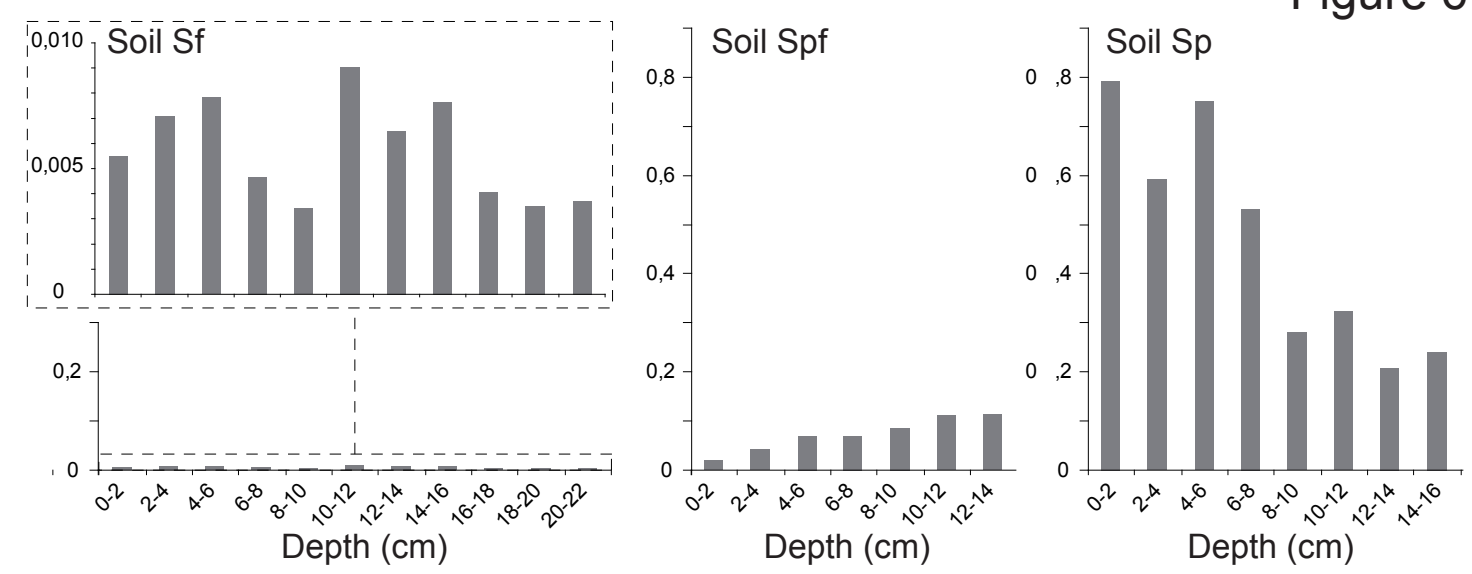

Figure 6

Depth $(\mathrm{cm})$ 
a. $n$-alkanes : $n-\mathrm{C}_{29} / n-\mathrm{C}_{31}$
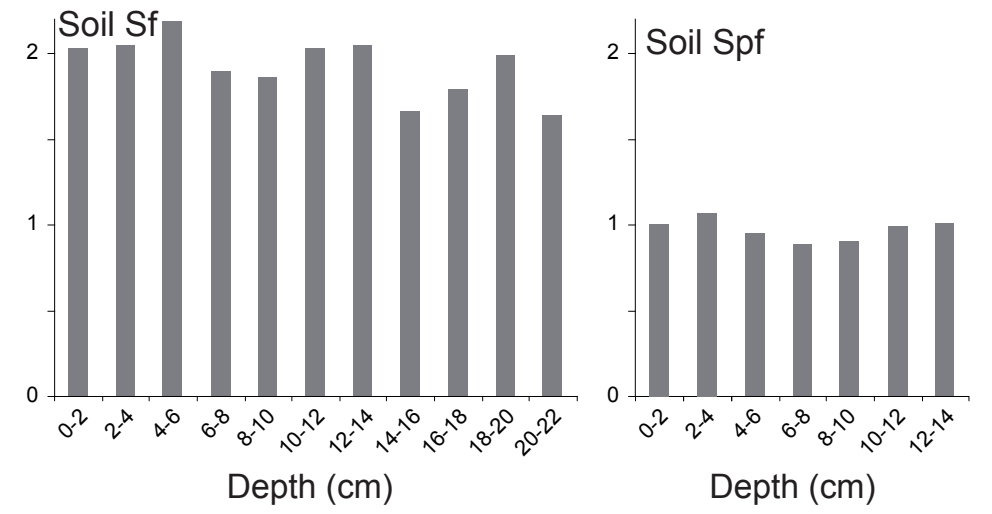

2 . Soil Sp

Figure 7

b. $n$-alkan-2-ones : $n$-C $29^{/ n-} \mathrm{C}_{31}$

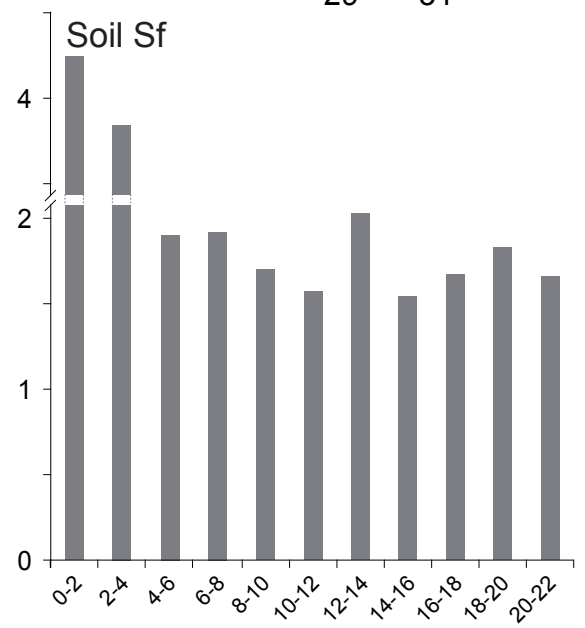

Soil Sp

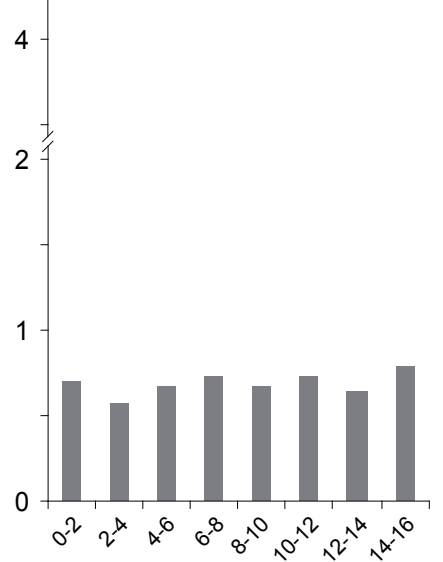




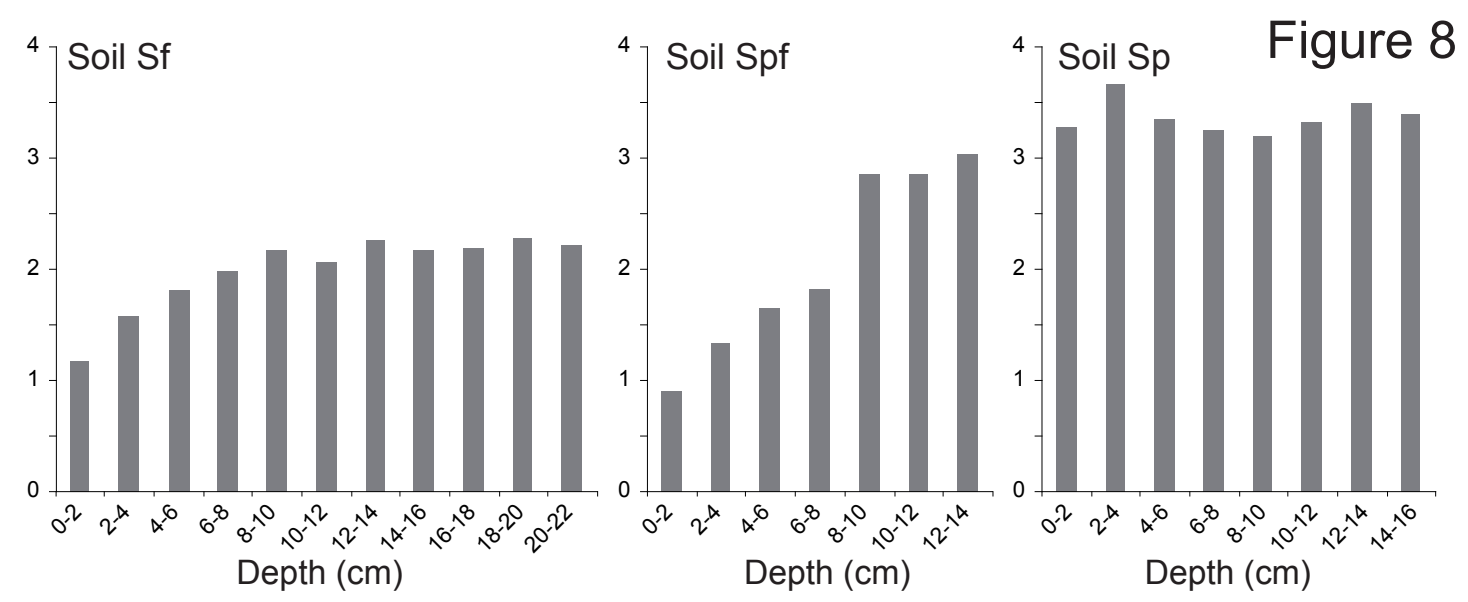

